\title{
Swift Strategies of Swift: An Investigation of the Concurrence of Poetic Politicality and Satiric Religiosity in the Works of Jonathon Swift
}

\author{
Nozen SeyedehZahra \\ Amin Police Science University, Iran \\ E-mail: nozenzahra@gmail.com
}

Received: 02-08-2016

Published: 10-12-2016
Accepted: 07-10-2016

doi:10.7575/aiac.ijalel.v.5n.7p.48
Advance Access Published: November 2016

URL: http://dx.doi.org/10.7575/aiac.ijalel.v.5n.7p.48

\begin{abstract}
"A childhood of neglect, an early career spent in a dependent position at Moor Park (Temple's house), a life of suspense and disillusionment at court,..." David Nokes, a biographer of Swift. Swift's acquaintance with Temple sharpened his literary imagination even though there had been many debates on Swift's position in Temple's household. His publication of Temple's writings drew Swift towards literature and literary production rather than politics and political affairs. Had it not been for his being attracted to writing through Temple's works in his youth and his literary circle in his maturity, Swift seemed to have a great tendency to be either a mere political writer or a sole church member. However, politics and religious issues never disappeared from his literary career and Swift never vanished wholly from political and religious arena. Politics is believed to have had most of his literary imagination under its control and Swift sometimes let his political thoughts be at liberty which he had kept forcibly in balance with literature during his literary life. For several times, politics defeated poetry in the internal struggle in Swift's personality the outcomes of which were his Examiner, pamphlets of Swift and Steele, A Modest Proposal and finally Drapier but each time Swift's artistic handling of the situation made posterity to think of him as a writer rather than a politician. For David Nokes "His most successful political writings are not his histories, in which he tries to unravel the skein of state events with the authority of an insider, but his satires, which demonstrate that ministers of state are merely footmen on stilts."
\end{abstract}

Keywords: Jonathan Swift, Satire, Gulliver's Travels, Politics

\section{Introduction}

Among his contemporary authors, Swift possessed a stronger political stand and a deeper awareness of the religious issues than the others. Swift had experienced a full betrayal of Whigs and a great disappointment of Tories and he had a detailed picture of nationwide sufferings of Irish people. Swift had witnessed public poverty and had observed closely how difficult a life beggars could possibly live!

This introduction may prepare his readers to detect more of religious, historical, political, educational and cultural facts in Swift's works because these factors seem to have sprung out of the writer's intentional splashing of political wrath over his works and deliberate loosening of his social grief in his writings. Swift is a politician whose tears are shed poetically and a poet whose cries can be heard over political disasters. He can be considered as a cheerful blending of poetic art with political insight in a manner of child-like innocence. The combination of the poetic tears and political cries brought about the composition of the greatest imaginative work ever attempted, which could be classified among classic satirical works and a children's classic at the same time. That work is: Gulliver's Travels.

Whatever he did, either as a politician or as a writer, Swift made magnificent efforts in translating the miseries of his people into art, speaking on their behalf in order to be heard, reflecting their agonies as well as their vanities and eventually he respected the public by making them believe that his works were their mouthpieces:

$$
\text { "...although the courtiers and gentry might despise him, the common people loved him."1 }
$$

Swift also acknowledged his great success in attracting public support. He might have been disappointed by politicians but his confidence in public opinion never ceased and ultimately he received their never-ending encouragement; "Swift still wielded great power and influence in Dublin." ${ }^{2}$ So he says:

"I walk the streets, and so do my lower friends, from whom, and from whom alone, I have a thousand hats and blessings."3

\footnotetext{
${ }^{1}$ David Nokes (1985). Jonathan Swift: A Hypocrite Reversed. New York: Oxford University Press. p.405.

${ }^{2}$ Ibid, p.404.
} 
Even in the passage of time the pain-giving situation of hell becomes bearable as Mammon predicts in Paradise Lost: "Our torments also may in length of time/Become our elements,"4 Man possesses such an ability which enables him to adopt easily to the new and even worse conditions and the characteristics of the new environment become a part of his existence in the long run. This might be counted as a meanness or an advantage for human being who is best known for his art of survival among other creatures. However, such an inclination for surviving in social dirt and political filth surely devaluates the high intentions of his creation. A satirist tries his best to warn public against the way of life that he has adopted.

The most recognized and largely practiced way of de-familiarization has always been accomplished by the application of a different angle to view the subject which was accustomed to be seen only from one dimension. This new angle of sight immediately shocks and defeats beholder's expectation. It has been mostly achieved by dispatching or receiving individuals as strangers to the habitual ways of living. His different experience of the adopted ways of public life brings about a wakefulness necessary for initiation of social movement which a satirist hopes for.

Swift employs Gulliver as an agent whose mission is de-familiarization. He dispatches Gulliver to worlds completely different from his own and that of ours. In doing so, Swift's main intention is to reveal the social vanities, cultural follies, political corruption, religious shallowness, deficiency in judicial systems, educational distortions and false perception of civilization. In a letter to his cousin, Sympson, Swift complains about the difficulty of removing -

$$
\begin{aligned}
& \text { "...Habit of Lying, Shuffling, Deceiving and Equivocating, so deeply rooted in the very Souls } \\
& \text { of all my Species; especially the Europeans." }
\end{aligned}
$$

Although the worlds which Gulliver navigates seem remote and unreachable, the relevance of their customs, social systems, political affairs, religious rituals and cultural norms to those of ours make every conscious reader feel that the events happening in Lilliput, Brobdingnag, Laputa or the country of the Houyhnhnms are not happening in distanced and detached locations but in our own backyard.

His intention is reformation, 'publick Good'. Swift hopes his Travels would put an end to all abuses and corruptions by the examples and precepts which he provides. Having his book read, Swift wishes to witness that -

$$
\begin{aligned}
& \text { "...Party and Faction were extinguished; Judges learned and upright; Pleaders honest and } \\
& \text { modest, with some Tincture of common Sense; and Smithfield blazing with Pyramids of Law- } \\
& \text { Books; the young Nobility's Education entirely changed; the Physicians banished; the } \\
& \text { Female Yahoos abounding in Virtue, Honour, Truth and good Sense; Courts and Levees of } \\
& \text { great Ministers thoroughly weeded and swept; Wit, Merit and Learning rewarded; all } \\
& \text { Disgracers of the Press in Prose and Verse, condemned to eat nothing but their own Cotten, } \\
& \text { and quench their Thirst with their own Ink." }
\end{aligned}
$$

Even though his wishes did not come true during his life time, these sentences embodied the pious statements which a politically oriented religious poet had in mind to execute.

\section{Diplomacy of Gulliver}

Gulliver is sent to four different destinations. His travels gift him a gradual self-education. Swift provides Gulliver a school-like context through his travels in which Swift is the tutor who, as gives Gulliver lessons and Gulliver learns them by experiencing a variety of contexts. Every education which does not lead to a positive change in the behaviour of the learner cannot be called knowledge or science. Therefore, in Swift's 'model school' Gulliver learns and changes for the better accordingly. Gulliver in Lilliput can no longer be judged as the same person among Houyhnhnms. Swift makes Gulliver learn through examples he is exposed to and Swift wishes that the same thing happens to his readers too. Gulliver cannot be said to have been used as a touchstone in his visits, but it can be claimed that his narration of a variety of incidents and diversions elects his readers as cosmopolitan multicultural juries who are well-informed by comparing two differently-approached cases and finally issue a unanimous verdict. This paper attempts to detect those cultural, political, religious, educational and social cases which seem to have been incorporated in the womb of pleasure-providing mother of all arts - literature - who gave birth to The Battle of the Books, A Tale of a Tub and especially Gulliver's Travels.

It must be clarified that Gulliver's Travel emerges in an age when travel adventures were admired and widely read. Public welcomed any such amusements in print with internal or external sources. Much of their readings material included translations. Daniel Defoe, whom Pope sometimes put beside other Grub-Street race as a dunce, had become popular with his adventurous books. In 1719, six years before Gulliver's Travels, Defoe had published Robinson Crusoe, a novel based on adventures of Alexander Selkirk on the Island of Juan Fernandez. The next year, having been encouraged by the wide acceptance of his first book, he published Adventures of Captain Singleton. It was followed by

\footnotetext{
${ }^{3}$ Harold Williams ed (1963). The Correspondence of Jonathan Swift. V Vols. London: Oxford University Press. V. p.50.

${ }^{4}$ John Milton, Paradise Lost. Book II, Line 274.

5 Jonathan Swift, (2000). Gulliver's Travels. New Delhi: Rupa \& Co. p.28.

${ }^{6}$ Ibid, p.26.
} 
the publication of the adventurous novel, Moll Flanders, in 1722. Such a rapid composition of travel books and adventurous novels could have made Swift speak in the language of his period. He might have thought if public were curious to have their imagination travel along with the hero of the exploratory novels, Gulliver would be able to satisfy their curiosity. As the beginning of the writing of Gulliver's Travels is believed to have been done early in 1721, five years before its publication, Defoe might have inspired Swift with the kind of its structure. It may be a true understanding of Wordsworth's concept of writing in "...the real language of men..." . So, Swift set his Gulliver on journey.

Swift's multiple journeys to and from Ireland were unavoidably made by ship. He gained a great amount of experiences by being exposed to travels made by ship. Names of captains and vessels, knowledge of longitude and latitude, the terminology used in navigation, map-reading, course plotting, steering, routing and seaman's slang might have been acquired by him during these voyages made by the sea between England and Ireland. Even in his friendly correspondence he did not fail to make use of sea or ship analogies:

"...I care not to live in Storms, when I can no longer do Service in the ship, and am able to get out of it." 8

or

"...You set out with the wind and tide against you; yet, at last, arrived at your port, from whence you are now driven back in open sea again."9

\section{Discussion of Political issues}

The importance of political issues in Swift's works, especially in Gulliver's Travels, becomes vivid when Gulliver is ultimately led to courts and palaces in all of his four voyages. Consequently, his presence in the middle of the political affairs of a country provides Swift with an appropriate opportunity to investigate their political doctrines thoroughly, match English and European politicians with theirs and when all is said and done, he diagnoses the defects of each in order to create a model of his reformist ideas.

Swift's account of political issues had always been with 'the authority of an insider'. As a considerable amount of his correspondence in the first three volumes reflects his desire to gain a governmental post which his education as a Doctor of Divinity qualified him for, Swift heaped a great amount of hatred on the ways in which these posts and positions were distributed. Even after he became the Dean of St Patrick church in Ireland, his application for a higher position never ended. Swift was never satisfied with the ways he was treated by the ministers of both the parties and mutually Whig and Tory leaders always felt that they had never granted him what he really deserved. Eventually, Swift's bitterness in ridiculing "...Candidates for great Employments and high Favour, at Court." 10 in the third chapter of the first book as "Rope-Dancers" 11 can be logically justified because he himself was a victim of such irrational and contemptible ways of preferment. Pope believed that his own life was 'a long disease' and relatively Swift's life can be credited as 'a long disappointment' due to the 'fatal accidents' which endangered candidates' lives.

For Swift, ministers and princes were sources of corruption and promoters of mental slavery in the society. Their ambition in ruling not only the country but the thoughts of his countrymen as well as their beliefs was never fulfilled. Politicians aimed at an absolute domination over their subjects. They demand laymen's obedience in every matter spiritual or worldly.

The third chapter of the first book of Gulliver's Travels deals with the most abhorrent political figure of the age, Sir Robert Walpole as Flimnap,

"...the Treasurer, is allowed to cut a Caper on the strait Rope, at least an Inch higher than any other Lord in the whole Empire..."

With such a show of his dexterity, Walpole reserved the title of being the first Prime Minister of Britain in 1721 after having been saved from breaking his 'neck', i.e. resignation from his office in 1717, by 'King's Cushions' ${ }^{13}$, Duchess of Kendal who helped his safe return to government in 1720.

Gulliver in Lilliput, possessing a bird's eye view over everything, mocks at the highly esteemed notions of kingdom, territory, troops, army, palace, His or Her Majesty etc. He gave the best military discipline on the top of a drum made from his handkerchief. Territory becomes "a more entertaining Prospect. The Country round appeared like a continued Garden;..." 14 The capital city of Lilliputians looked like the painted scene of a city in a theatre. Ladies and courtiers seemed to resemble a petticoat spread on the ground, embroidered with figures of gold and silver. The army and troops

\footnotetext{
${ }^{7}$ William Wordsworth "Preface to Lyrical Ballads". G. B. Harrison et al eds (1959). Major British Writers. 2 Vols. United States of America: Harcourt, Brace \& World, INC. ii. p.18.

${ }^{8}$ Harold Williams ed (1963). The Correspondence of Jonathan Swift. V Vols. London: Oxford University Press., ii. p.30.

${ }^{9}$ Ibid, ii. p.111.

${ }^{10}$ Jonathan Swift (2000). Gulliver's Travels. New Delhi: Rupa \& Co. p.53.

${ }^{11}$ Ibid.

12 Ibid.

${ }^{13}$ Ibid, p.54.

14 Ibid, p.43.
} 
of the country, which are a source of pride and honour for every patriotic citizen, were laughed at by having them paraded in close order and marched under Gulliver's open legs. His majesty was taller than the other courtiers almost by the breadth of Gulliver's nail. For a better view of him, Gulliver must have laid on one side. However, such a dwarf was addressed as:

\begin{abstract}
“...most Mighty Emperor of Lilliput, Delight and Terror of the Universe, whose Dominions extend five Thousands Blustrugs, (about twelve Miles in Circumference) to the Extremities of the Glob: Monarch of all Monarchs: Taller than the Sons of Men; whose Feet press down to the Center, and whose Head strikes against the Sun: At whose Nod the Princes of the Earth shake their Knees;..."15
\end{abstract}

The juxtaposition of opposites brings the self-deceptive descriptions which kings in general have of themselves and which George-I in particular had of himself. Court flatterers had a good share in making kings and ministers believe in their inaccurate and fallacious images. The futility, hollowness and worthlessness of these concepts can be discovered only if one looks through glasses of reality and stands on a higher and detached stand than earthly attachments which Swift made it possible for his readers through Gulliver.

The inapprehensibility of political dialogue is another issue which was touched upon when Gulliver tried to establish communication with the royal families in the courts and palaces of all the strange lands he visits during his travels. In Lilliput "His Imperial Majesty spoke often to me, and I returned Answers, but neither of us could understand a Syllable." 16 The two parties involved in the act of communication spoke two totally different languages with the least degree of mutual comprehension, but still they seemed to be busy in communicating. Kings and ministers, unaware of national demands of their subjects, addressed them in their futile speeches. Swift, in a very simple example of Gulliver's talks with the Lilliputian king, demonstrates the total collapse of understanding, communication between the authorities and their nation.

Again, in Laputa the same issue is dealt with more intensity. The people of Laputa, like those of Lilliput, especially king and ministers, were so engaged in mathematics that they could not think about other things:

"...Minds of these People are so taken up with intense Speculations, that they neither can speak, or attend to the Discourses of others."17

After his departure from Temple's house, Swift came back to London for several times on missions in relation with Irish affairs. He met and visited several parliamentarians, party leaders and ministers to discuss Ireland and its problems, but in spite of his long stays in London, every time he returned to Ireland empty-handed. Politicians did not keep their promises and they totally forgot Swift's Irish issues. This was a great disappointment for Swift. In the third voyage, Swift proposes 'bladder and flapper' for those politicians whose “...Thoughts and Minds were more disengaged." 18 On an occasion of meeting Walpole, Swift was not only disappointed with the usual forgetfulness and lack of attention of political figures which he was accustomed to, but he was badly injured with the contemptuous and insulting behaviour of Walpole. So, he retaliates in the sixth chapter of Laputa the offensiveness of Walpole who was at that time the prime minister:

"...whoever attended a first Minister, after having told his Business with the utmost Brevity, and in the plainest Words; should at his Departure give the said Minister a Tweak by the Nose, or a Kick in the Belly, or tread on his Corns, or lug him thrice by both Ears, or run a Pin into his Breech, or pinch his Arm black and blue; to prevent Forgetfulness."19

Public administration has always proved to be obscure from the very beginning of civilization. From western Plato to eastern Confucius, there had been many political thinkers who came forth with many solutions to the obscurity of politics. However, they, one after another, suffered many defeats. Theories of Marx and Lenin were buried in their birthplace. History of human beings shows that man's mind produced best of his theories in political affairs, but his over-ambition made them all ineffective when they were put into practice. Many utopias were sketched on papers, but they became just castles in the air when it came to putting them into practice. Even today mankind is proud of its technological advancement and boasts of its inventions of mega systems and computers, but the irony is that a liberating system of administration like democracy is being exported under the wings of bombers.

In such a turmoil, the conscientious soul of the age is left with no other alternative but to ridicule, satirize and mock at the baseless pretentious politicians whom Matthew Arnold dubbed as charlatans. Swift's inventive imagination depicted the deceptive party-game played by politicians and political parties of his times as is reflected in the politics played by Tramecksan (High Heels) and Slamecksan (Low Heels) in Lilliput. When a king determines to:

\footnotetext{
${ }^{15}$ Jonathan Swift (2000). Gulliver's Travels. New Delhi: Rupa \& Co. p.58.

${ }^{16}$ Ibid, p.45.

${ }^{17}$ Ibid, p. 177.

18 Ibid.

${ }^{19}$ Ibid, p.207.
} 
"...make use of only low Heels (who were in minority) in the Administration of the

Government, and all Offices in the Gift of the Crown." 20

even the imagination of the sight in which a great amount of social energy and wealth were wasted upon trivial political oppositions based on the height of their heels is also lamentable. High Heels exceeded Low Heels in number, but the power was wholly on the side of Low Heels. Such a strategy can better be described as public destruction and elimination of age-old, respectable, beneficial foundations of a civil society rather than public administration.

The situation becomes even worse when the heir of the king has one of his heels higher than the other. The doubt and uncertainty surrounding the whole administrative body, which faced an inevitable total collapse, would certainly confine their productivity. Therefore, Swift - aware of the destructive affairs of the court, king, ministers and palace which was already burning in the flames of their ignorance and short-sightedness - was left with no other alternative but to treat the palace in such an abhorrent manner. Now that the king is not ashamed of discharging his wrath, rage and ignorance which had brought about literary, cultural, social, economic and political corruption on which Swift would also shamelessly make an assault in return by having his Gulliver as the representative of the public discharge of their urine on the palace fire because there was no hope of any peaceful reformation of the corrupt situation for which kings and ministers must be blamed.

Swift and other honourable poets were accused of and punished for disclosing ministers' corruptions and opposing them as such disclosures and oppositions ironically were looked upon as 'crimes' instead of commendable deeds which they in fact were considering the welfare of the public.

"...she having born perpetual Malice against you, on Account of that infamous and illegal Method you took to extinguish the Fire in her Apartment." 21

It is good to remember that in addition to the prosecution of the publisher of Swift's A Proposal for the Universal Use of Irish Manufacture, twice a reward of three hundred pounds was declared for Swift's head: first in 1714 for the anonymous writer of The Public Spirit of the Whigs and secondly in 1724 for Letters to the Whole People of Ireland.

The main political injury of the eighteenth century England from which not only Swift but other free-thinkers also were suffering was the authoritarian pressure which was exerted on different strata of society in order to make them think and speak as the princes, kings and ministers wished them to do. According to Swift, people were supposed to see through the eyes of the kings and the ministers. "Justice might in some measures be satisfied,..."22 if the eyes of Quinbus Flestrin, Gulliver, were put out. In the political dilemma of the eighteenth century England, people were supposed to have the eyes which did not see and the ears which did not hear and the heart which did not feel. The outside world must have been perceived, referred to and understood through the senses of the ministers;

"...it would be sufficient for you to see by the Eyes of the Ministers, since the greatest Princes do no more."23

Swift ridicules and at the same time objects to this damned fashion and political norm of the period by justifying Gulliver's decision to prefer to flee to Blefuscu - seemingly Belfast, the capital of Northern Ireland - rather than to submit to the cruel impeachment and inhumane injustice of losing his eyes which meant the blind obedience of the authorities. Doing so, Swift's self-exile seemed logical as his countryman, James Joyce, forced Stephen Dedalus of $A$ Portrait of the Artist as a Young Man to set himself on the road not taken. Starving the poets siding with the opposition party and those having the independent views on public matters was another policy of the government to suppress its rivals upon which Swift touched by depicting the project of starving Gulliver in Lilliput:

“...for want of sufficient Food, you would grow weak and faint, and lose your Appetite, and consequently decay and consume in a few Months;..." 24 .

Concept of liberty in the real sense of the term was what Gulliver was searching for wherever he went. Even the advantage of the bodily strength in Lilliput and Blefuscu, the joys of royal courtesy in the country of Brobdingnag, the pleasure of the presence on the flying island of Laputa and the spiritual satisfaction of being among virtuous creatures of Houyhnhnms could not quench his thirst for freedom and Swift destined Gulliver to live with the hope of being a citizen of a free country rather than to be free in a foreign territory.

The voyage to Laputa has never been widely accepted like other three travels of Gulliver. In Laputa, adventurous Gulliver gradually fades away and gives his place to politically-loaded and philosophically-affluent Swift. Direct statements, fewer actions, more speech and descriptive allotment might have lightened the literary value of this voyage

\footnotetext{
${ }^{20} J o n a t h a n$ Swift (2000). Gulliver's Travels. New Delhi: Rupa \& Co. p.63.

${ }^{21}$ Ibid, p.87.

22 Ibid, p.86.

23 Ibid.

${ }^{24}$ Ibid, p.87.
} 
and hardened the bitterness of its satire, but the weight and significance of the incredible poetic imagination of the voyage as a whole grants it its survival among the other three fictitious travels.

England, with its small population insisted, imposed and preserved its domination over other completely different nations. Scotland, Ireland and Wales had been forcibly and theoretically yoked under the title of United Kingdom while the history of rebels, uproars, oppositions and Jacobite movements has always proved opposite of 'United' in practice and in real life. Whatever the pretence of equality and mutuality of their relationship could be offered by London to the other three territories, the residents and inhabitants of those regions were aware of London's role as an oppressor who drains their wealth under royal patents and endangers their freedom with its 'standing army'. London could only be interpreted as a black cumulonimbus cloud scattered over other farms, which after gathering its strength and existence from the vapours of their water, natural wealth, gifts them back with a sudden outbreak of hailstones and thunderstorm.

Wood's Royal Patent for coining halfpence in Ireland was one of these examples. He purchased the patent for five thousands pound and thought of gaining gross benefit out of his investment. Swift in a letter to Charles Ford dated April $2^{\text {nd }} 1723$ refers to it as a "Destructive business" 25 and in another letter to Lord Carteret calls it "...the most ruinous project that ever was contrived against any nation." ${ }^{26}$ During these years the composition of the third voyage of Gulliver's Travels, Laputa, and Drapier's Letters was going on. The celebration of its cancellation through Swift's resistance is reflected in his letter of August 31, 1725;

"Since Wood's patent is cancelled ... The work is done, and there is no more need of the Drapier."27

Irish wealth was sucked up in this way and in return they were paid by the negligence of English rulers of Ireland in getting jobs and preferment:

"Since your Excellency hath had an opportunity so early in your Government of gratifying your English Dependents by Bishoprick and the best Deanery in the Kingdom, I cannot but hope that the Clergy of Ireland will have their Share in your Patronage." 28

It seems there could not be any other fictional, poetic and also realistic way of depicting such a relationship so beautifully apart from Swift's Laputa in relation to Balnibarbi, Lagado and Malonada. The floating or flying island of Laputa, over which king and his ministers resided, used to receive taxes from the lands under its sovereignty and hover over rebellious lands as a black omen.

"If any Town should engage in Rebellion or Mutiny, fall into violent Factions, or refuse to pay the usual Tribute; the King hath two Methods of reducing them to Obedience. The first and the mildest Course is by keeping the Island hovering over such a Town, ... deprive them of the Benefit of the Sun and the Rain... And if the Crime deserve it, they are at the same time pelted from above with great Stones... the Roofs of their Houses are beaten to Pieces. But if they still continue obstinate, or offer to raise Insurrections; he proceeds to the last Remedy, by letting the Island drop directly upon their Heads, which makes a universal Destruction both of Houses and Men." ${ }^{29}$

Even today, after three centuries, Swift's invented political image is widely used in terms of sanctions and embargos under the supervision and legitimacy of the United Nations. In an age when, even the inventors of aeroplanes had not been born, Swift could predict the second stage - heavy aerial bombardment. Envisaging the last remedy, conquering and occupying other lands and countries, years before the outbreak of even the First World War, endorses Swift's imaginative power with an authority beyond the reach of the temporality and spatiality of any other science.

\section{Discussion of Religious issues}

Swift, the novelist, as a Dean, was the man of church who was officially involved in religious affairs. Therefore, in addition to other issues, an especial attention should be devoted to religious issues because it would be amiss to neglect Swift's religious opinions as representative of the spiritual ideology of the age. Swift, who possessed university degree of Doctor of Divinity, occupied the charge of St Patrick Deanery for most of his life. In a number of his letters to his fellow Deans, bishops and archbishops and in his published sermons, Swift conveyed directly his views on contemporary religious situation, but as the literary handling of his religious thoughts and satirically wrought of them are the concern of the critical study of Swift's works, so this paper deals with those religious views wrapped up in literary form.

In 1704 when Swift was 37 years old, two years after graduation from Trinity College as a Doctor of Divinity and twenty-two years before the composition of Gulliver's Travels, the three brothers in A Tale of a Tub epitomized the

\footnotetext{
${ }^{25}$ Harold Williams ed (1963). The Correspondence of Jonathan Swift. V Vols. London: Oxford University Press. iii. p. 10 .

${ }^{26}$ Ibid, p. 12.

${ }^{27}$ Ibid, p.93.

${ }^{28}$ Ibid, p. 70 .

${ }^{29}$ Jonathan Swift (2000). Gulliver's Travels. New Delhi: Rupa \& Co. pp.189\&190.
} 
earthly corruptors of divinely plain coats of religion. Being equipped with the fresh religious education of Trinity College, Swift's imagination was deliberately cast over every minute novelty which had been imposed upon Christianity in the passage of time. His trained and impeccable eyes could detect every defect in the all-known and well-known Christian sects.

The true Christianity embodied in their father's will and coats was gradually interpreted and changed according to the taste and fashion of the day. The Bible, the doctrines and Christian faith were left to the mercy of three merciless vices: covetousness, ambition and pride. Plainness of religion was violated with unnecessary ornament of pageantry. Tradition was allowed to have equal authority with the holy book. Images of saints, the blessed virgin with an infant as the saviour, the moon and the lamb were added and considered as holy as the Bible itself. Peter became 'Mr. Peter, then Father Peter; Emperor Peter, Lord Peter' and at last the blasphemous titles such as "God upon Earth, God Almighty and sometimes Monarch of the Universe" ${ }^{30}$ were used to refer to him. Indulgences were sold:

"Whenever it happened that any rouge of Newgate was condemned to be hanged, Peter would offer him a pardon for a certain sum of money,..."31

It is the invention of new mechanism by church which is also depicted in The Beggar's Opera.

If religion has been believed to be a celestial and heavenly call from Providence for unity, knowledge, submission, obedience, peace and prosperity, how can the historical contradictions of the hostile executions, blood-curdling invasions, ruthless massacres, social separations, bloody rebels and cruel destructions in the name of religion be justified? There has been rarely any war in which no footprints of religious motivation are traced. Religion entails "...six Rebellions raised..."32, "...eleven Thousand Persons have, at several Times, suffered Death,..."33, exile and refuge when Swift mentions it in Gulliver's Travels for the first time. This is the corruption which contaminated religion not only in Swift's time but throughout history. Manipulation of religious beliefs has been a main strategy for enslaving nations, encouraging soldiers, stirring public emotions, controlling the masses, assuring oppression and whatever initiation necessary for erecting, preserving and continuing absolute authority and rule. Thus, these were the crimes committed in the name of religion for the fulfilment of personal ambitions of the rulers. In this regard poor, pure and innocent religion was used as an instrument for achieving evil purposes as Swift in An Apology for a Tale of a Tub warns about: "Religion being the best of things, its corruptions are likely to be the worst."

It seems logical to think that Swift's thought in Gulliver's Travel was confined to Lilliput and in the process of the composition of the first voyage or by the completion of it, the idea of the second one struck him. His later acquaintance and close contact with horses in real life loaded his imagination with Houyhnhnms depicted in the fourth voyage. If so assumed, a kind of inner struggle can be detected in the composition of the first book. In the beginning of the fourth chapter of the first voyage, Swift hesitates to talk about wars and politics, laws, learning and religion of Lilliputians, but by the end of the same chapter, he discloses what he promised to be published separately in "...a greater Work, which is now almost ready for Press;..." $"$. It might have been said either for his doubt about inserting religion among other issues or raising readers' curiosity and laying the ground for his attack on religious corruption. Swift might have had in his mind his unpublished History of the Four Last Years of Queen. Whatever was his intention, Swift, finding the proper opportunity and having no thought of writing the other voyages at the time of writing the first, gives the religious corruption of the eighteenth century what it deserved - a thorough exposure of malpractices, corruptions, in it. His bitter attack on the shallowness of the perception of religion was equal to or even more than the corruption that religion had suffered from. People of great talent in mathematics, deep planning in children's education, cautious in details of their Image of Justice were vitally sinking down and drowning in the shallow water of their ignorance of celestial belief. The immediate artistic courageous allusion to the religious bewilderment of Europeans in spite of their tremendous scientific achievements is what makes Swift's satire on religious issues a masterpiece.

Big-Endians or Little-Endians, a terminology invented by Swift as new religious sects, came into existence by the prejudiced misinterpretation of the holy text of the Lilliputian prophet: "That all true Believers shall break their Eggs at the convenient End." 35 The invention of terms such as Catholic, Protestant, Quaker and Pretenders might have some causes as trivial as that of Lilliputian. The passage of time had proven that 'the ancient practice' of breaking egg from its big end was 'convenient' till an ignorant immature king, in his childish venture, finding it dangerous to the continuity of his kinghood, when he happened to cut his finger, commands “....all his Subjects, upon great Penalties, to break the smaller End of their Eggs." ${ }^{36}$ In such circumstances, resistance and resentment are unavoidable. Exile, execution, murder, war, bloodshed and imprisonment should be considered as natural descendants of politicallymotivated and dictatorially-imposed innovations of totalitarians in religion. This disturbs the unity, knowledge, submission, obedience, peace and prosperity which religion promised, prophets were sent for, politicians tarnished,

\footnotetext{
${ }^{30}$ Jonathan Swift “A Tale of a Tub”. Angus Ross and David Woolley eds (2003). Jonathan Swift: Major Works. Oxford: Oxford University Press. pp.111\&116.

${ }^{31}$ Bryan Loughery and T. O. Treadwell eds (1986). The Beggar's Opera. London: Penguin Books. p.115.

${ }^{32}$ Jonathan Swift (2000). Gulliver's Travels. New Delhi: Rupa \& Co. p.64.

${ }^{33}$ Ibid.

${ }^{34}$ Ibid, p. 62.

${ }^{35}$ Ibid, pp.64\&65.

${ }^{36}$ Ibid, p. 64.
} 
public neglected and poets fought till they flourished on 'the waste land' and till the songs of 'Shantih shantih shantih' could be heard once again.

\section{Conclusion}

Swift fights such a battle for re-accession of spirituality throughout the four voyages of Gulliver in order to educate Gulliver explicitly during his travels in search of 'quest' and implicitly the public cursed with 'death wish' and damned with Grub Street. He seems to be victorious because Gulliver who, in the first voyage, armed with knife, pistol, gun, gunpowder, gold, silver and comb and who lacked any sign of religion such as cross, holy book or even any other book or written material - as per the 'Inventory' made of his belongings - was fascinated by the virtue, honesty, rationality and generosity in the last voyage.

Alexander Pope in his The Rape of the Lock was more hopeful than Swift because at least on Belinda's dressing table beside 'Puffs, powders, patches' there could be found a Bible or lovers' letters. Belinda wore a cross "which Jews might kiss, and infidels adore." Gulliver's condition was more severe. He had only the earthly items of war and business. Swift deprived him of any mental worth and dignity. However, ethereal elements could not save Pope's Belinda, but lower earthly dumb creatures like horses could save Swift's Gulliver. Pope starts with hope and ends in despair. Swift starts with confusion and ends in salvation. Pope believed in divine help and miraculous saving. Swift made it possible by practical methods of contemplating over habitual customs in order to gain a better understanding.

\section{References}

Brown, A., and Keymy, J.L. (1977). Satire: An Anthology. New York: Crowell.

Bullitt, J. M. (1953). Jonathan Swift and the Anatomy of Satire: A Study of Satiric Technique. Cambridge: Mass, Harvard UP.

Carlson, L. H. and Paulson, R. (1972). English Satire. Los Angeles: University of California.

Conway, W. E. (1976). Satire on Women. Los Angeles; California: The Augustan Reprint Society

Craman, P. L., and Phythian, B. A. (1991). Encyclopaedia of Dates and Events. Third edition. London: Hodder \& Stoughton.

Crook, K. (1998). A Preface to Swift. London; New York: Addison Wesley Longman Ltd.

Downie, J. A. (1984). Jonathan Swift: Political Writer. London; Boston: Routledge \& Kegan Paul.

Eliot, R. C. (1960). The Power of Satire. Princeton: Princeton University Press.

Johnson, Samuel (1980). Lives of the English Poets: Life of Swift. London: George Bell and Sons.

Leavis, F. R. (1952). Swift's Irony: The Common Pursuit. London: Chatto and Windus.

Loughery, Bryan. and Treadwell T. O. eds (1986). The Beggar's Opera. London: Penguin Books

Murry, J. M.(1954). Jonathan Swift: A Critical Biography. London: Jonathan Cape.

Nokes, D. (1985). Jonathan Swift: A Hypocrite Reversed. Oxfordshire and New York: Oxford University Press.

Ross, A., and Woolley, D. (2003). Jonathan Swift: Major Works. Oxford: Oxford University Press.

Williams, H. (1963). Jonathan Swift; Journal to Stella. 2 Vols. London: Oxford University Press.

Williams, H. (1963). The Correspondence of Jonathan Swift. V Vols. London: Oxford University Press. 